\title{
Perspectives
}

\section{Assessing human sperm morphology: top models, underdogs or biometrics?}

\author{
Jacques Auger \\ Service d'Histologie-Embryologie, Biologie de la Reproduction/CECOS, Hôpital Cochin, Paris 75014, France
}

\begin{abstract}
The assessment of the percentage of spermatozoa having an 'ideal' morphology using so-called strict method is the method recommended in the latest edition of the World Health Organization (WHO) laboratory manual for semen analysis. This recommendation is a result of the statistical association between 'ideal' sperm morphology and fertility, and of the current general belief that sperm morphology assessment should be used primarily as a fertility tool. The notion of an 'ideal' sperm morphology has persisted despite the very low percentage of such spermatozoa in the semen of fertile men, a subject of intense controversy. The detailed categorization of each abnormal spermatozoon has thus, for a long time, been considered optional and partially redundant, an idea which is reflected in the earlier editions of the WHO manual. However, several recent studies have shown the importance of carefully assessing abnormal sperm morphology for use in the diagnosis of infertility, to determine fertility prognosis, and for basic or public health studies. One approach, which combines videomicroscopy and computer vision, and is the only approach able to assess the continuum of sperm biometrics, has been used successfully in several recent clinical, basic and toxicology studies. In summary, the visual assessment of detailed sperm morphology-including the categorization of anomalies allowing arithmetically derived indices of teratozoospermia - and the more modern computer-based approaches, although often considered to be redundant, are in fact complementary. The choice of the most appropriate method depends on the field of investigation (clinical, research, toxicology) and the problem being addressed. Each approach has advantages as well as certain limitations, which will be discussed briefly herein.
\end{abstract}

Asian Journal of Andrology (2010) 12: 36-46. doi: 10.1038/aja.2009.8

Keywords: diagnosis, fertility prognosis, image analysis, multiple anomalies index, pattern recognition, reproductive toxicology, sperm defects, sperm deformity index, sperm pathology, teratozoospermic index, videomicroscopy

\section{Introduction}

Mammalian spermatozoa are highly differentiated cells. Their particular structural organization results from complex morphogenetic changes during spermiogenesis. These include (i) the formation of the acrosome derived from Golgi vesicles, (ii) the formation of an axoneme from the distal centriole, surrounded by periaxonemal structures, which together form the flagellum, (iii) the migration and development of mitochondria in a helicoidal sheath around the axoneme in the midpiece, (iv) the

Correspondence to: Dr Jacques Auger, Service d'Histologie-Embryologie, Biologie de la Reproduction/CECOS, Hôpital Cochin, 123 Bd, de Port Royal, 75014 Paris, France.

Fax: +331-5841-1565
Received: 12 November 2008

E-mail: jacques.auger@cch.aphp.fr Accepted: 1 December 2008 formation of an anisotropic sperm head (with a ellipsoid face and a pear-shaped profile) containing a highly condensed nucleus and, (v) the disappearance of the vast majority of the cytoplasm. In other words, during this final fundamental step of spermatogenesis, haploid round spermatids displaying normal cellular anatomy - typically, a round cell with a central rounded nucleus surrounded by the usual cellular organelles - gradually turn into testicular spermatozoa, which, in the simplest terms, are made of a head, a midpiece and a principal piece: the principal piece is hereafter referred to as the tail. These highly specialized cells transform the cellular components required to fulfil their physiological functions: moving progressively to transport a copy of the haploid genome to, and to interact with, the oocyte, thereby delivering its genetic information through fertilization. This transformation of the spermatid, leading to the assembly of the sperm cell, does not proceed 
in successive stages; rather, it follows a continuous process for the assembly of each subcellular component. Although testicular spermatozoa in the seminiferous tubule lumen have the same appearance as ejaculated spermatozoa, they are not fully mature in either molecular composition or organization when they leave the testis. Indeed, they gain their full fertilizing potential mainly during their migration through the epididymis.

The scenario described above would be the ideal one. However, in humans, the microscopic examination of sperm morphology shows that this complex morphogenetic process is not very efficient, generating spermatozoa with various abnormal and imperfect features. It is imperative that scientists analyze the causes of these imperfections and their possible consequences for fertility.

\section{Sperm morphology in native semen samples and in samples from the female genital tract}

When examining several microscopic fields of stained smears of ejaculated spermatozoa from either infertile or healthy fertile men, the most striking observation is that spermatozoa that are morphologically 'unfinished', 'immature' or malformed with marked morphological heterogeneity outnumber the morphologically 'ideal' sperm cells. This is markedly different from observations of other mammalian species, the vast majority of which produce spermatozoa with a mature, more uniform morphology.

Thus, the generation of more immature and abnormally shaped spermatozoa may be a consequence of complex factors that disrupt spermiogenesis and may reflect a lower potential for fertilization under natural conditions. However, the appearance of spermatozoa that have migrated in cervical mucus or through cumulus cells is markedly different, that is, these spermatozoa are much more normal [1-4]. This morphological selection process depends on the intrinsic ability of the sperm cell to migrate actively in the female genital tract and on the physical characteristics of the milieu encountered [5]. Most spermatozoa found in the vicinity of the oocyte have the morphological appearance of the 'ideal' spermatozoa that are expected to emerge from non-disrupted spermiogenesis. This observation has led to the idea of defining normal sperm morphology in semen on the basis of the microscopic characteristics of well-proportioned spermatozoa from the female genital tract [6]. Such a concept is reminiscent of the more general concept of the structure-function relationship used by a pathologist. However, it should be noted that the observation by light microscopy, even of an optimally stained smear observed at a final magnification of $\times 1000$, does not allow for the functional assessment of a sperm cell. Although there is a clear association between the structure and function in a normally shaped and stained flagellum of a spermatozoon that has migrated in cervical mucus, the same cannot be assumed to be true for a spermatozoon observed in a native semen sample; the sperm tail may appear morphologically normal despite an axoneme anomaly resulting in cell immotility [7]. Similarly, a perfectly oval head shape with a normal texture does not necessarily reflect chromatin maturity [8] or the absence of DNA fragmentation [9]. In contrast, ideally shaped spermatozoa found at the zona pellucida appear to have normal mature chromatin [4].

3 Spermatozoa with 'ideal' morphology (the 'top models'): their mature morphology suggests an optimal fertilizing potential

Despite these limitations, the observation of spermatozoa that have migrated in the female genital tract, and their morphological and biometric characteristics has led to the definition of a morphologically normal spermatozoon. The selected criteria form a practical basis for assessing ideally shaped spermatozoa in the ejaculate or under other conditions such as after selection on a density gradient or with the use of a swim-up procedure. The significantly increased percentage of normal spermatozoa found after sperm selection [10] and the finding of statistical associations between the percentage of normal spermatozoa and various fertility endpoints, notably in in vitro fertilization [11], were the main arguments invoked to recommend the use of these criteria for defining normal sperm morphology. These data contributed to the 1999 World Health Organization (WHO) consensus for recommending this approach, the so-called strict method, for assessing normal sperm morphology [12]. This guideline is still included in the forthcoming edition of the manual. The innovative nature of using strict definitions for describing sperm morphology should be stressed. Indeed, before it was developed, several classification methods were used with vague definitions or no definitions at all, making it difficult to obtain consistent results from different observers. Such absent or vague definitions often resulted in percentages of normal spermatozoa being as high as $80 \%$, with differences of $30 \%$ or more between two observers scoring the same slide.

\section{Is it sufficient to focus only on morphologically 'ideal' spermatozoa?}

Is this rapid and easy-to-use approach, which essentially focuses on spermatozoa with an 'ideal' morphology, sufficient for the different contexts requiring morphological analysis of spermatozoa? The editorial staff of the fourth edition of the WHO manual recommended the use of a single method for classifying morphologically normal spermatozoa using strict method. However, in another section, the manual 
stated that a detailed categorization of the morphological abnormalities might be useful [12]. Compared with the fourth edition, the forthcoming edition of the WHO manual reinforces the suggestion that focusing on abnormal sperm morphology may be useful by providing markedly improved photographic examples of sperm abnormalities with detailed descriptions (but not definitions as for the morphologically normal spermatozoon) and by developing further the various indices of teratozoospermia (see below). However, the forthcoming edition of the WHO manual still does not provide precise procedures for classifying the different categories of anomalies, and it is not clearly said when it should be useful to categorize abnormal sperm morphology.

The examination of human sperm morphology is currently generally considered to be a tool devoted to the clinic and to the fertility prognosis. This is undoubtedly related to the fact that semen analysis is mostly prescribed by gynaecologists in the context of a couple trying to conceive. The andrologist or reproductive biologist then has to analyze the semen sample mainly with the aim of determining a prognosis. Notably, it is generally believed that this analysis will mainly serve to direct decisions on assisted reproduction technologies (ART) options. The question simply addressed is: are there enough morphologically normal (that is, with a theoretically optimal fertilizing potential) spermatozoa? Alternatively, the aim of the analysis may be to determine the probability of a negative effect of such a large number of abnormalities on fertility either in vivo or in vitro. Of course, clinicians who consider semen analysis to be restricted to prognosis purposes, particularly in cases of ART, may believe that examining only morphologically normal spermatozoa is sufficient, particularly as several studies have shown a statistical association between these spermatozoa and fertility $[11,13,14]$. However, a number of studies have also reported on the prognostic value of analyzing abnormal morphology and using various indices of teratozoospermia for fertility either in vivo or in vitro [15-18]. It could therefore be of interest, and potentially useful, to study whether fertility is correlated to normal and abnormal sperm morphology to equivalent extents. Some data suggest that natural fertility could share a stronger association with abnormal morphology than normal morphology [16], but this remains to be confirmed.

The most controversial aspect of analyzing normal sperm morphology based on the strict method is the extremely low percentage of normal morphology reported for normal fertile men [19-21]. The very low proportion of normal spermatozoa, despite being consistent with the number of typical spermatozoa found in the vicinity of the oocyte, leads one to ask: are the criteria used to define the 'ideal' sperm morphology too strict? On the basis of these criteria, how is this characteristic distributed in a population of fertile men? This will be presented in the forthcoming edition of the WHO manual. Taking into account the recommended confidence intervals for the percentages of morphologically normal spermatozoa estimated from the observation of 200 sperm cells, what should we think of the discriminative power of the 'ideal' morphology, with thresholds of $12 \%$ and $9 \%$ in fertile and infertile men, respectively [22]? If the values within a population of fertile men do not vary greatly (for example, between $5 \%$ and $25 \%$ ), would it be possible use this variable to distinguish between two men with markedly different probabilities of fertilization over a given time (for example, time to pregnancy [TTP] of 2 vs. 9 months)? There is currently no conclusion to this issue; the debate continues.

The low values obtained for the percentages of morphologically normal spermatozoa using the strict method also raise the question of the relevance of these criteria. Everyone agrees on the need to have precise criteria for defining ideal morphology and to have a sound basis for the criteria selected (see above). However, the notion of a continuum of shapes and sizes of sperm cells raises the question of the classification of spermatozoa with shapes and sizes close to the defined thresholds for 'normality'. The WHO 1999 classification guidelines state that any sperm cells with subnormal features (borderline) should be considered abnormal. I am unaware of any evidencebased data showing that small variations in the size, shape or texture of sperm cells with a generally subnormal appearance lead to significant changes in fertilizing potential. In the French modified classification of David $[23,24]$, which is rarely used outside French-speaking countries, the definition of morphologically normal sperm cells is the same as that defined by the strict method approach, except that subnormal shapes, sizes or textures are considered normal unless there is evidence to suggest otherwise. In a study by Slama et al. [18], based on almost 1000 male partners of pregnant women, two successive centralized analyses of stained smears were carried out, using either the strict method or David's criteria of normal sperm morphology. As expected, the mean percentages of spermatozoa with a normal morphology were about $15 \%$ $20 \%$ higher with David's method, with a strong correlation between the values obtained by the two methods $(r=0.49$, $P<0.00005)$. The two curves assessing the association with likelihood of pregnancy had similar profiles, with a threshold value of $39 \%$ for David's method and $19 \%$ for the strict approach, beyond which neither approach provided significantly discriminative values. Below these threshold values, the profiles of the curves and their intercepts with the y-axes suggest that better discrimination is achieved if borderline spermatozoa are considered to be normal (Figures 1A and B). 
These issues are currently considered only in the context of prognostic evaluation during the follow-up of couples attending consultations for infertility. However, the role of the reproductive biologist/andrologist is not limited to the description of sperm morphology to determine fertility prognosis. Like pathologists interpreting the description of a microscopic preparation from a biopsy in a known clinical context, the reproductive biologist/ andrologist, having observed, described and categorized a sample of spermatozoa on a stained semen smear, should provide a 'biological diagnosis' that is adapted to the context. Why is such a small number of sperm cells properly assembled, and how do history, disease, treatment or environmental factors impair spermiogenesis? Unfortunately, only few sperm morphological profiles are indicative of a specific history or particular environmental factors. In contrast, it has been shown that several sperm abnormalities have a precise genetic origin, notably when a single abnormality predominates (for an extensive review, see [25]).

Many kinds of environmental factors and chemicals have been shown to affect human sperm quantity and quality $[26,27]$. Several clinical and epidemiological studies have revealed a statistical association between these factors and abnormal spermiogenesis, or different fertility end points $[24,28,29]$. The known vulnerability of the human testis to many physical, chemical [30] or more complex factors (for example, psychological stress; [31]) suggests that analysis of sperm morphology can serve as a valuable indicator of the impact of toxic, or genotoxic, effects of occupational, lifestyle or environmental factors on the testis.

\section{Methods for assessing human sperm morphology}

There are two methods for examining human sperm morphology, both based on the microscopic analysis of stained smears, either through visual observations (manual methods) or by using computer vision-derived methods. For either of these methods, a smear must be optimally stained to provide sharp contrast for defining the sperm outline and cell details. Recognition of these features also depends on the final magnification-generally $\times 1000$ with the manual method combining a $\times 100$ oil objective with a $\times 10$ ocular lens. Pre-analytical procedures have been described, and guidelines can be found in the fourth edition of WHO laboratory manual [12].

Using a standard microscopic approach, the observer categorizes each sperm cell as normal or abnormal, and eventually classifies each anomaly encountered using strictly defined criteria. By contrast, computer-assisted technology measures different morphological features (mostly head parameters) for each selected sperm cell.
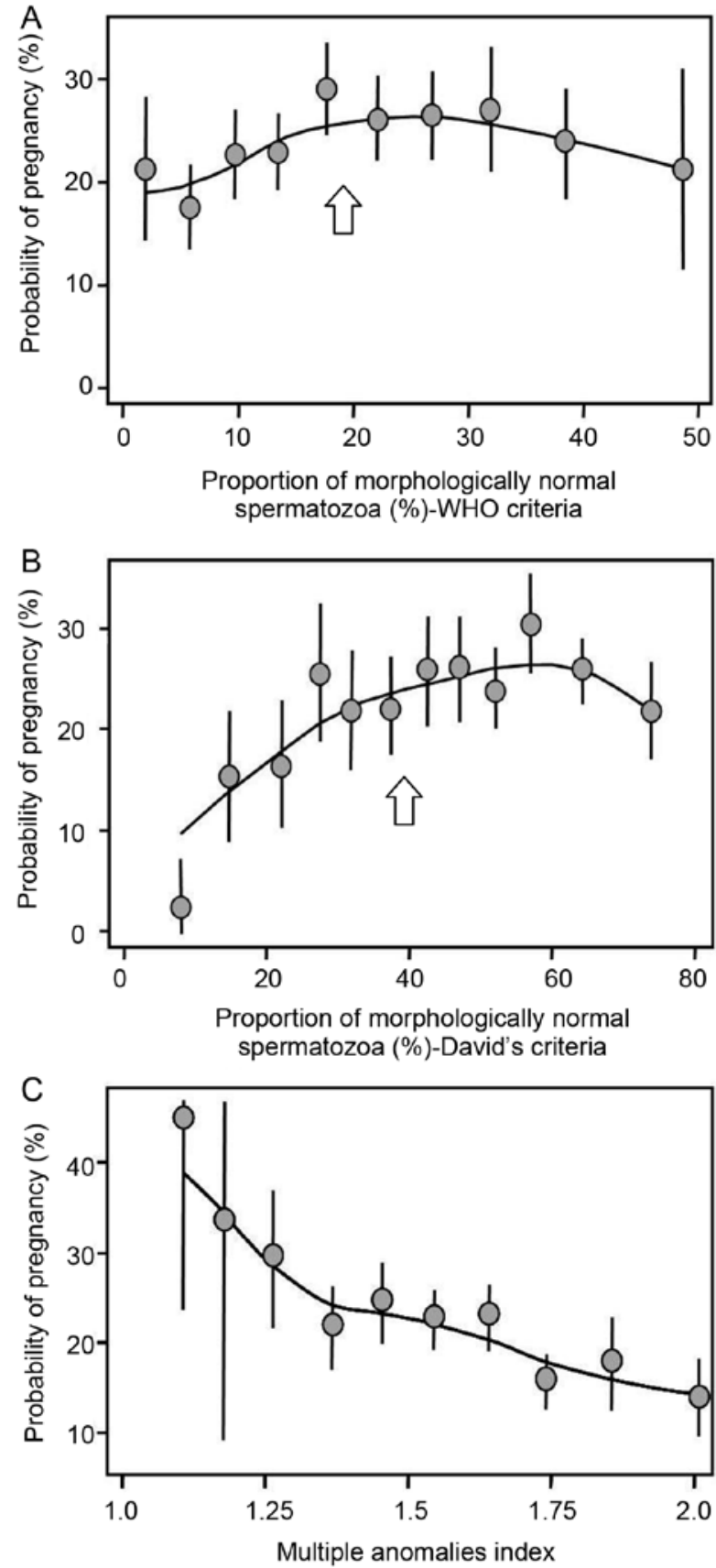

Figure 1. Unadjusted probability of pregnancy per month of attempt at pregnancy, based on normal morphology using World Health Organization (WHO) strict method (borderline = abnormal [A]), modified David's criteria (borderline = normal [B]), and multiple anomalies index (MAI [C]) in a population of 942 fertile European couples. Reproduced from Slama et al. [18]. In this study, thresholds were found by both approaches: $19 \%$ with the WHO method and 39\% with the method of David; there was no threshold for MAI. 
The visual classification of morphologically normal spermatozoa has been discussed above. Below, I discuss the potential benefits of focusing more on morphologically abnormal spermatozoa or sperm defects than on those meeting the 'ideal criteria'.

\section{Describing abnormal spermatozoa (the 'underdogs'): a difficult but essential exercise}

Defective spermatogenesis is commonly associated with an increased percentage of spermatozoa displaying several head, midpiece and/or tail defects. Few spermatozoa exhibit only a single defect. A number of morphological defects signify an abnormal process of sperm morphogenesis and likely reduced fertilizing ability. All sperm cells observed in the stained smear are classified as 'normal' or 'abnormal'. Abnormal sperm cells are then further categorized into subgroups according to the defects observed (for example, concerning the head and/or midpiece and/or tail). This requires subgroups to be defined precisely, relying on expertise in light/ electronic microscopy and/or on the evidence-based data on associations between the sperm defects categorized, and on functional anomalies, as is the case in the French classification (Table 1; $[23,24]$ ). This has proven to be useful for diagnosis, prognosis and research purposes [2, $8,15,16,18,24,32,33]$. The fourth edition of the WHO manual [12] lists categories of sperm defects that should be noted; however, precise definitions of each category are not given. In addition, for accurate and comparable results, definitions for subcategorization should be stated. For example, should defects be evaluated by considering only one defect per compartment (head, midpiece or tail)? If yes, which one? Alternatively, should all defects observed in each abnormal spermatozoon be considered together (David's approach)?

\section{Usefulness of sperm polymalformation indices}

Most morphologically abnormal spermatozoa have multiple defects. Recording the morphologically normal spermatozoa together with details of abnormalities observed for the head, midpiece and tail in a multiple-entry system gives the mean number of abnormalities per spermatozoon examined. Three indices have been proposed earlier: (i) the multiple anomalies index (MAI, [16]), (ii) the teratozoospermia index (TZI, [34, 35]), and (iii) the sperm deformity index (SDI, [36]). The MAI is calculated as the mean number of anomalies per abnormal spermatozoon. All head, midpiece and tail anomalies are included in the calculation. The TZI is similar, but as only one abnormality per spermatozoon compartment is counted, it only accounts for at most one head, one midpiece and one tail anomaly for each abnormal spermatozoon, independent of the real number of total anomalies. The SDI is the number of defects divided by the total number of spermatozoa (including abnormal and normal spermatozoa); it has several categories of head anomaly, but only one for each midpiece and tail defect. Laboratory cell counters can be used, with the number of entry keys adapted to the type of index used.

Despite being conceptually different, MAI and TZI in fertile and infertile populations are similarly distributed: the median and tenth percentile values for the MAI in 994 healthy fertile men partners of pregnant women and in 4930 partners of infertile couples were measured to be 1.58 and 1.34 vs. 1.94 and 1.51, respectively ([24]; Auger, unpublished data). The median and tenth percentile values for TZI in 107 healthy fertile men partners of pregnant women and in 103 partners of infertile couples were 1.54 and 1.33 vs. 1.81 and 1.74, respectively [35]. These indices are correlated with fertility in vivo (MAI: [16, 18] [note that, as indicated in Figure 1, there is no threshold, as there is a pseudo-linear relationship between MAI and the probability of pregnancy]; TZI: [35]) and with in vitro fertilization (SDI: [36]), and may be useful when assessing various environmental factors or pathological conditions $[24,37,38]$.

\section{Limits of visual approaches: quality control absolutely necessary}

The level of variability in the assessment of sperm morphology for either normal spermatozoa or for sperm defects is relatively extensive. However, it should be pointed out that the inter-observer variability found for several anomaly categories could be lower than for normal spermatozoa [39]. Variability may be considerably reduced by standardizing the analytical methods, and by providing sufficient basic knowledge and training [39] with periodic internal and external quality control testing $[40,41]$. However, some of the variability is linked to the continuous nature of sperm shape and size, and thus cannot be eliminated, making the classification of subnormal shape and size difficult. The use of an eyepiece with a graduated reticle may be very useful to correctly assess sperm size defects (for example, distinguishing a marginally 'thin' head vs. a 'normal' head).

One major factor that renders visual assessment of sperm morphology difficult is the fact that this analysis depends on mechanisms of human vision and their integration in the brain. Visual observation is subject to several limitations. The eye-brain combination is a powerful tool in pattern recognition (far better than 'machine vision'), but is poorly adapted to measurement. This is reflected by the higher inter-observer variability in determining the total percentage of spermatozoa with 
Table 1. Morphological abnormalities ${ }^{\mathrm{a}}$ and sperm pathology.

\begin{tabular}{|c|c|c|c|c|}
\hline $\begin{array}{l}\text { Sperm defect }{ }^{\mathrm{a}} \\
\text { (Light microscopy, final ma }\end{array}$ & 0]) & $\begin{array}{l}\text { Possible related } \\
\text { TEM observations }\end{array}$ & $\begin{array}{l}\text { Possible associated } \\
\text { functional anomaly }\end{array}$ & Reference \\
\hline $\begin{array}{c}\text { Elongated head } \\
\text { Major axis } \uparrow \\
\text { Minor axis }=\end{array}$ & & $\begin{array}{l}\text { Abnormally } \\
\text { shaped head and } \\
\text { abnormally } \\
\text { condensed } \\
\text { chromatin }\end{array}$ & $\begin{array}{l}\text { Immature } \\
\text { chromatin/fragmented } \\
\text { DNA (possible } \\
\text { disadvantage for embryo } \\
\text { development?)/increased } \\
\text { aneuploidy }\end{array}$ & $\begin{array}{l}\text { Dadoune et al. [8]; } \\
\text { Gandini et al. [47]; } \\
\text { Prisant et al. }[48]\end{array}$ \\
\hline $\begin{array}{l}\text { Thin head } \\
\text { Major axis }= \\
\text { Minor axis } \downarrow\end{array}$ & & $\begin{array}{l}\text { Abnormally } \\
\text { shaped head and } \\
\text { abnormally } \\
\text { condensed chromatin }\end{array}$ & $\begin{array}{l}\text { Immature } \\
\text { chromatin/fragmented } \\
\text { DNA (possible disadvantage } \\
\text { for embryo development?) }\end{array}$ & $\begin{array}{l}\text { Dadoune et al. [8]; } \\
\text { Gandini et al. }[47]\end{array}$ \\
\hline $\begin{array}{c}\text { Microcephalous head } \\
\text { Major axis } \downarrow \\
\text { Minor axis } \downarrow\end{array}$ & & $\begin{array}{l}\text { Excessive } \\
\text { shrinking of the } \\
\text { nucleus and abnormally } \\
\text { condensed chromatin }\end{array}$ & $\begin{array}{l}\text { Immature } \\
\text { chromatin/fragmented } \\
\text { DNA }\end{array}$ & $\begin{array}{l}\text { Dadoune et al. [8]; } \\
\text { Gandini et al. [47] }\end{array}$ \\
\hline $\begin{array}{c}\text { Macrocephalous head } \\
\text { Major axis } \uparrow \\
\text { Minor axis } \uparrow\end{array}$ & & $\begin{array}{l}\text { Insufficient shrinking } \\
\text { of the nucleus and } \\
\text { abnormally condensed } \\
\text { chromatin }\end{array}$ & Increased aneuploidy & Benzacken et al. [49 \\
\hline $\begin{array}{l}\text { Multiple heads } \\
\text { More than one head }\end{array}$ & & $\begin{array}{l}\text { Two or more closed or } \\
\text { dissociated heads } \\
\text { with or without a } \\
\text { common acrosome } \\
\text { or midpiece }\end{array}$ & $\begin{array}{l}\text { Handicaps migration } \\
\text { through mucus and } \\
\text { oocyte vestments/fragmented } \\
\text { DNA }\end{array}$ & Gandini et al. [47] \\
\hline $\begin{array}{l}\text { Abnormal postacrosome } \\
\text { region } \\
\text { All outline and texture } \\
\text { anomalies of the region }\end{array}$ & & $\begin{array}{l}\text { Abnormally shaped } \\
\text { post-acrosomal } \\
\text { component and } \\
\text { disorganization of } \\
\text { the cape structures; } \\
\text { abnormal DNA } \\
\text { condensation }\end{array}$ & $\begin{array}{l}\text { (Possible disadvantage } \\
\text { for gamete interaction?) }\end{array}$ & $\begin{array}{l}\text { Gandini et al. [47]; } \\
\text { Courtot et al. [50]; } \\
\text { Longo et al. }[51] ; \\
\text { Escalier [52] }\end{array}$ \\
\hline $\begin{array}{l}\text { Abnormal acrosome } \\
\text { region } \\
\text { All outline, size and } \\
\text { texture anomalies of } \\
\text { the region }\end{array}$ & & $\begin{array}{l}\text { Absent or abnormally } \\
\text { shaped or sized } \\
\text { acrosome, incomplete } \\
\text { acrosome and/or } \\
\text { abnormal appearance } \\
\text { of the underlying nucleus }\end{array}$ & $\begin{array}{l}\text { Abnormal-impossible } \\
\text { acrosome } \\
\text { reaction/fragmented } \\
\text { DNA (possible disadvantage } \\
\text { for gamete interaction/ } \\
\text { embryo development?) }\end{array}$ & $\begin{array}{l}\text { Albert et al. [53]; } \\
\text { Gandini et al. [47]; } \\
\text { Holstein et al. [54] }\end{array}$ \\
\hline $\begin{array}{l}\text { Abnormal residual } \\
\text { cytoplasm } \\
\text { Residual cytoplasm } \\
>30 \% \text { of head size }\end{array}$ & & $\begin{array}{l}\text { Abnormally wide } \\
\text { cytoplasmic remnant } \\
\text { containing subcellular } \\
\text { components }\end{array}$ & $\begin{array}{l}\text { Handicaps migration } \\
\text { through cervical mucus } \\
\text { and oocyte vestments/a } \\
\text { possible disadvantage } \\
\text { for gamete interaction/ } \\
\text { source of ROS }\end{array}$ & $\begin{array}{l}\text { Courtot et al. [50]; } \\
\text { Gomez et al. [55] }\end{array}$ \\
\hline $\begin{array}{l}\text { Thin midpiece } \\
\text { Diameter of midpiece } \\
<\text { diameter of the } \\
\text { proximal principal piece }\end{array}$ & & $\begin{array}{l}\text { Partial or absent } \\
\text { mitochondrial sheath }\end{array}$ & $\begin{array}{l}\text { No or reduced ATP } \\
\text { available for cell } \\
\text { propelling }\end{array}$ & Zamboni [56] \\
\hline
\end{tabular}


Table 1. Morphological abnormalities ${ }^{\mathrm{a}}$ and sperm pathology (continued).

\begin{tabular}{|c|c|c|c|c|}
\hline \multicolumn{2}{|c|}{$\begin{array}{l}\text { Sperm defect }{ }^{\mathrm{a}} \\
(\text { Light microscopy, final magnification }[\times 1000])\end{array}$} & $\begin{array}{l}\text { Possible related } \\
\text { TEM observations }\end{array}$ & $\begin{array}{l}\text { Possible associated } \\
\text { functional anomaly }\end{array}$ & Reference \\
\hline $\begin{array}{l}\text { Bent tail } \\
\text { Not aligned with } \\
\text { midpiece and head } \\
\text { or sharply bent } \\
\text { midpiece/tail }\end{array}$ & & $\begin{array}{l}\text { Misaligned midpiece } \\
\text { and head or sharply } \\
\text { bent midpiece/tail }\end{array}$ & $\begin{array}{l}\text { Impairment of syngamy } \\
\text { and cleavage; abnormal } \\
\text { cell propelling: } \\
\text { handicaps migration } \\
\text { through mucus and } \\
\text { oocyte vestments }\end{array}$ & $\begin{array}{l}\text { Chemes et al. [57]; } \\
\text { Saïas-Magnan [58] }\end{array}$ \\
\hline $\begin{array}{l}\text { Absent tail } \\
\text { Isolated head, } \\
\text { no tail observed }\end{array}$ & - & $\begin{array}{l}\text { Various anomalies } \\
\text { of the neck region }\end{array}$ & $\begin{array}{l}\text { Fragility of the neck } \\
\text { structures Sperm } \\
\text { propulsion not possible }\end{array}$ & \\
\hline $\begin{array}{l}\text { Short tail } \\
\text { Tail length }<5 \\
\text { head lengths }\end{array}$ & & $\begin{array}{l}\text { Abnormally shaped } \\
\text { periaxonemal and } \\
\text { sometimes axonemal } \\
\text { structures/dysplasia of } \\
\text { the fibrous sheath }\end{array}$ & $\begin{array}{l}\text { Immotility or severe } \\
\text { dyskinesia }\end{array}$ & Chemes et al. [59] \\
\hline $\begin{array}{l}\text { Irregularly shaped } \\
\text { tail } \\
\text { Irregular/changing } \\
\text { caliber along the tail }\end{array}$ & & $\begin{array}{l}\text { Abnormally shaped } \\
\text { periaxonemal and } \\
\text { sometimes axonemal } \\
\text { structures }\end{array}$ & $\begin{array}{l}\text { Abnormal motion } \\
\text { (sliding spermatozoa, } \\
\text { for example) } \\
\text { (possible disadvantage } \\
\text { for gamete interaction?) }\end{array}$ & Feneux et al. [60] \\
\hline $\begin{array}{l}\text { Coiled tail } \\
\text { Completely or } \\
\text { partially coiled tail }\end{array}$ & & $\begin{array}{l}\text { Completely or } \\
\text { partially coiled tail } \\
\text { often within a huge } \\
\text { cytoplasmic remnant }\end{array}$ & $\begin{array}{l}\text { Sperm propulsion } \\
\text { not possible }\end{array}$ & \\
\hline $\begin{array}{l}\text { Multiple tails } \\
\text { More than one tail }\end{array}$ & & $\begin{array}{l}\text { Partially dissociated } \\
\text { tails connected to a } \\
\text { single or to multiple } \\
\text { heads or tails knitted } \\
\text { together over a variable } \\
\text { length }\end{array}$ & $\begin{array}{l}\text { Abnormal motion: } \\
\text { handicaps migration } \\
\text { through mucus oocyte } \\
\text { vestments (possible } \\
\text { disadvantage for } \\
\text { gamete interaction) }\end{array}$ & \\
\hline
\end{tabular}

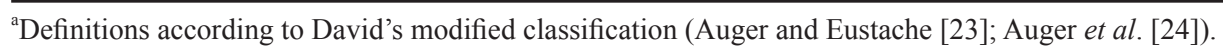

size defects compared with spermatozoa with a qualitative anomaly [39]. In general, visual classification under the microscope of morphologically normal and abnormal spermatozoa, categorizing all visible defects according to their definitions, requires the assessment of cellular and subcellular sizes (sperm head size, tail length, residual cytoplasm area, etc.), size ratio (between-sperm size comparison) and pattern recognition (multiple heads or tails, absent tail, coiled tail, etc.). One way to replace the poor visual capacity for assessing the continuum of sperm sizes, shapes and textures would be to quantify sperm morphology with the assistance of a computer.

\section{Computer vision: sperm biometrics reveals the impact}

\section{of various factors disrupting sperm morphogenesis with potential functional consequences}

Over the last three decades, image cytometry has been increasingly used in cell biology. This approach allows for the precise and reproducible measurement of cell structure and function. Image cytometry generally relies on image analysis systems that combine microscopy, video and data processing. It is based on the measurement of absorbed light at each point of a sperm cell on a stained smear under a microscope. These measurements can then be reiterated by scanning all the points making up the cell or subcellular compartment studied to give a representative image in the form of a numerical matrix (each point of the image 
source is 'represented' by its co-ordinates in the field of analysis and by a grey scale value). This is stored in the image analysis system to be subsequently processed by specific algorithms. Quantitative information describing this image can then be extracted. Computer-assisted videomicrography was the basis of integrated systems brought onto the market in the mid-1980s. Today they are used in many andrology laboratories worldwide. These devices, usually termed computer-aided sperm analysis (CASA) instruments, machines or systems, were primarily developed to measure sperm concentration, the percentage of motile spermatozoa and various characteristics of sperm movement. This technology has since been applied to basic sperm morphometry, densitometry or texture analysis $[42,43]$, or used secondary to a morphometric and densitometric step for visually assisted categorization, mainly of sperm heads (for example, IVOS CASA software based on the 'strict' criteria classification system
$[44,45])$. To obtain useful information from the visual assessment of sperm morphology, it is essential that the quality of the preparation, choice and quality of fixing, thickness of the preparation, choice of dyes, type of light and adjustment of optics are carefully chosen [46].

Multipurpose image analysis systems have been used for determining sperm biometrics in various clinical or research contexts. Over the past decade, a number of pioneering studies have shown the usefulness of such approaches in the clinic and for reproductive toxicology or research purposes. Table 2 lists selected articles published on this topic. It is not yet known whether such approaches can be routinely used for the assessment of human sperm morphology. However, one well-recognized major limitation of computer-assisted sperm morphology is the inability of such an approach to categorize sperm defects easily, in particular of those involving pattern recognition, a skill that requires extensive software development at a

Table 2. Computer-based biometrics of human spermatozoa: selected literature.

\begin{tabular}{|c|c|c|c|}
\hline Application & Parameters & Image analysis system & References \\
\hline $\begin{array}{l}\text { Consequences of sperm preparation } \\
\text { methods on head morphometry }\end{array}$ & $\begin{array}{l}\text { Major axis, minor axis, elongation factor, } \\
\text { head area, head perimeter, acrosomal area } \\
(\% \text { of head area })\end{array}$ & Metrix (Hamilton-Thorn) & $\begin{array}{l}\text { Lampiao and } \\
\text { du Plessis [61] }\end{array}$ \\
\hline $\begin{array}{l}\text { Assessment of human sperm head } \\
\text { features (fertile donors) }\end{array}$ & $\begin{array}{l}21 \text { parameters, morphometry (size and } \\
\text { shape), densitometry (DNA condensation) } \\
\text { and texture (DNA distribution patterns) }\end{array}$ & $\begin{array}{l}\text { Computerized karyometric } \\
\text { image analysis (CKIA) }\end{array}$ & Ramos et al. [62] \\
\hline $\begin{array}{l}\text { Sperm integrity pre- and post- } \\
\text { chemotherapy in men with testicular } \\
\text { germ cell cancer }\end{array}$ & & & Spermon et al. [63] \\
\hline $\begin{array}{l}\text { Dimensional assessment of } \\
\text { X-bearing and Y-bearing haploid } \\
\text { and disomic human sperm }\end{array}$ & $\begin{array}{l}\text { Head area, perimeter, long axis, short } \\
\text { axis, shape factor and elliptical form } \\
\text { factor and tail length, including the } \\
\text { midpiece (tail delineated manually using } \\
\text { an optical mouse device) }\end{array}$ & $\begin{array}{l}\text { Computer-based } \\
\text { metamorph program }\end{array}$ & Zavaczki et al. [64] \\
\hline $\begin{array}{l}\text { Association between 'zona } \\
\text { pellucida preferred' sperm } \\
\text { morphometry and pregnancy rate } \\
\text { in subfertile couples }\end{array}$ & $\begin{array}{l}32 \text { parameters describing dimensions, } \\
\text { symmetry and distribution of stain } \\
\text { density of sperm heads }\end{array}$ & $\begin{array}{l}\text { Sperm head automated } \\
\text { morphometric analysis } \\
\text { system }\end{array}$ & Garrett et al. [65] \\
\hline $\begin{array}{l}\text { Morphometric differences in } \\
\text { mature and immature human } \\
\text { spermatozoa }\end{array}$ & $\begin{array}{l}\text { Manual delineation of the tail, } \\
\text { midpiece and head regions; } \\
\text { measurement of tail length, head } \\
\text { diameter, area, long axis, perimeter } \\
\text { and shape factor }\end{array}$ & $\begin{array}{l}\text { Image-1 analysis system } \\
\text { (Universal Imaging Corp.) }\end{array}$ & Gergely et al. [66] \\
\hline $\begin{array}{l}\text { Quantification and classification } \\
\text { of human sperm morphology } \\
\text { Effects of psychological stress } \\
\text { on human sperm quality }\end{array}$ & $\begin{array}{l}\text { More than } 20 \text { variables assessing } \\
\text { sperm head, including stain content, } \\
\text { length, width, perimeter, area and } \\
\text { arithmetically derived combinations, } \\
\text { followed by unsupervised classification }\end{array}$ & $\begin{array}{l}\text { Quantitative image } \\
\text { processing system }\end{array}$ & $\begin{array}{l}\text { Moruzzi et al. [42] } \\
\text { Fenster et al. [67] }\end{array}$ \\
\hline $\begin{array}{l}\text { Longitudinal assessment of } \\
\text { sperm head morphometry of } \\
\text { unexposed workers }\end{array}$ & $\begin{array}{l}\text { Head length, width, area, perimeter, } \\
\text { width/length ratio and oval factor }\end{array}$ & $\begin{array}{l}\text { Automated image analysis } \\
\text { system (Model 3000, Image } \\
\text { Technology Corp.) }\end{array}$ & Schrader et al. [68] \\
\hline
\end{tabular}


prohibitive cost.

\section{Summary}

There is no standard multi-purpose method for assessing human sperm morphology for fertility diagnosis, prognosis, reproductive toxicology, basic research or public health studies. However, the current approaches discussed herein contain advantages and limitations, which vary as a function of the clinical or research context. Therefore, it is important to consider these as complementary approaches, rather than as either exclusive or redundant tools for the assessment of multiple aspects of the microscopic anatomy of human spermatozoa (summarized in Table 3). Further guidelines for the assessment of sperm morphology could therefore account for the advantages and limitations of each method as mentioned in Table 3, and could provide a basis for selecting the optimal approach for a given application. A laboratory involved in the diagnosis of male infertility and ART should not only evaluate typical spermatozoa, but also categorize the various sperm defects, allowing for the calculation of a useful teratozoospermia index. This proposal can also apply to epidemiological studies (with a centralized assessment in case of a multicentre study). Finally, for basic or toxicological studies investigating the effects of various occupational or environmental factors,

Table 3. Assessment of human sperm morphology by visual observation or computer vision (propositions for considering the advantages, limitations and usefulness of each current approach as a function of the study aims and domain for future guidelines).

\begin{tabular}{|c|c|c|c|c|}
\hline $\begin{array}{l}\text { Background in } \\
\text { humans }\end{array}$ & \multicolumn{4}{|c|}{$\begin{array}{l}\text { Most of the spermatozoa leaving the testis are morphologically immature and/or abnormally shaped/sized: } \\
\text { causes and consequences? }\end{array}$} \\
\hline $\begin{array}{l}\text { Approaches } \\
\text { for assessing } \\
\text { human sperm } \\
\text { morphology } \\
\end{array}$ & \multicolumn{3}{|c|}{$\begin{array}{c}\text { Stained smear } \\
\text { Conventional microscopy } \\
\text { Visual observation with } \\
\text { categorization/classification }\end{array}$} & $\begin{array}{c}\text { Stained smear } \\
\text { Conventional microscopy } \\
\text { Computer vision }\end{array}$ \\
\hline Characteristics assessed & $\begin{array}{l}\% \text { morphologically } \\
\text { normal sperm }\end{array}$ & and/or & $\begin{array}{l}\% \text { morphologically abnormal } \\
\text { sperm in each abnormality category }\end{array}$ & Sperm morphometry \\
\hline \multirow{3}{*}{$\begin{array}{l}\text { Advantages and limits } \\
\text { of each method }\end{array}$} & \multicolumn{2}{|c|}{ Qualitative and semi-quantitative } & Qualitative and semi-quantitative & Quantitative \\
\hline & \multicolumn{2}{|c|}{$\begin{array}{l}\text { - Easy to use routinely } \\
\text { - Rapid } \\
\text { - Mainly focused on sperm head } \\
\text { assessment } \\
\text { - Marked inter- and intra-observer } \\
\text { variability }\end{array}$} & $\begin{array}{l}\text { - Useful for diagnosis } \\
\text { - Useful for prognosis } \\
\text { - Time consuming } \\
\text { - Marked inter- and intra-observer } \\
\text { variability }\end{array}$ & \multirow{2}{*}{$\begin{array}{l}\text { - Accuracy } \\
\text { - Reproducibility } \\
\text { - Facilitates etermination } \\
\text { of subtle induced } \\
\text { morphology changes } \\
\text { - Correlations easily } \\
\text { determined } \\
\text { - Costly } \\
\text { - Mainly dedicated to } \\
\text { sperm head and not } \\
\text { tail morphometry } \\
\text { - Allows subsequent } \\
\text { supervised visual } \\
\text { sorting/categorization } \\
\text { - Basic computer vision } \\
\text { perfect for measuring, } \\
\text { but not adapted to } \\
\text { complex pattern } \\
\text { recognition (cost) }\end{array}$} \\
\hline & \multicolumn{3}{|c|}{$\begin{array}{l}\text { Allows integration of an informative abnormality index (MAI/SDI/TZI) } \\
\text { Eye-brain coupling well-adapted for pattern recognition, not for measuring }\end{array}$} & \\
\hline \multicolumn{5}{|l|}{$\begin{array}{l}\text { Usefulness according to } \\
\text { the application }\end{array}$} \\
\hline Infertility diagnosis & \multicolumn{2}{|l|}{++} & +++ & $+?$ \\
\hline ART & \multicolumn{2}{|l|}{+++} & ++ & $+?$ \\
\hline Reproductive toxicology & \multicolumn{2}{|l|}{+} & + & +++ \\
\hline Basic research & \multicolumn{2}{|l|}{+} & ++ & +++ \\
\hline
\end{tabular}


a quantitative approach based on image analysis might be preferred to detect induced subtle modifications of the sperm dimensions or head densitometry.

\section{References}

1 Barros C, Vigil P, Herrera E, Arguello B, Walker R. Selection of morphologically abnormal sperm by human cervical mucus. Arch Androl 1984; 12 (Suppl): 95-107.

2 Jeulin C, Soumah A, Jouannet P. Morphological factors influencing the penetration of human sperm into cervical mucus in vitro. Int J Androl 1985; 8: 215-23.

3 Menkveld R, Franken DR, Kruger TF, Oehninger S, Hodgen GD. Sperm selection capacity of the human zona pellucida. Mol Reprod Dev 1991; 30: 346-52.

4 Liu DY, Baker HW. Sperm nuclear chromatin normality: relationship with sperm morphology, sperm-zona pellucida binding, and fertilization rates in vitro. Fertil Steril 1992; 58: 1178-84.

5 Katz DF, Drobnis EZ, Overstreet JW. Factors regulating mammalian sperm migration through the female reproductive tract and oocyte vestments. Gamete Res 1989; 22: 443-69.

6 Ombelet W, Menkveld R, Kruger TF, Steeno O. Sperm morphology assessment: historical review in relation to fertility. Hum Reprod Update 1995; 1: 543-57.

7 Eliasson R, Mossberg B, Camner P, Afzelius BA. The immotilecilia syndrome. A congenital ciliary abnormality as an etiologic factor in chronic airway infections and male sterility. N Engl J Med 1977; 297: 1-6.

8 Dadoune JP, Mayaux MJ, Guihard-Moscato ML. Correlation between defects in chromatin condensation of human spermatozoa stained by aniline blue and semen characteristics. Andrologia 1988; 20: 211-7.

9 Avendaño C, Franchi A, Taylor S, Morshedi M, Bocca S, et al. Fragmentation of DNA in morphologically normal human spermatozoa. Fertil Steril 2009; 91: 1077-84.

10 Menkveld R, Swanson RJ, Kotze TJ, Kruger TF. Comparison of a discontinuous Percoll gradient method versus a swimup method: effects on sperm morphology and other semen parameters. Andrologia 1990; 22: 152-8.

11 Kruger TF, Menkveld R, Stander FS, Lombard CJ, Van der Merwe JP, et al. Sperm morphologic features as a prognostic factor in in vitro fertilization. Fertil Steril 1986; 46: 1118-23.

12 World Health Organization. WHO Laboratory Manual for the Examination of Human Semen and Sperm-Cervical Mucus Interaction, 4th edn. Cambridge: Cambridge University Press; 1999.

13 Enginsu ME, Dumoulin JC, Pieters MH, Bras M, Evers JL, et al. Evaluation of human sperm morphology using strict criteria after Diff-Quik staining: correlation of morphology with fertilization in vitro. Hum Reprod 1991; 6: 854-8.

14 Kobayashi T, Jinno M, Sugimura K, Nozawa S, Sugiyama T, et al. Sperm morphological assessment based on strict criteria and invitro fertilization outcome. Hum Reprod 1991; 6: 983-6.

15 Jeulin C, Feneux D, Serres C, Jouannet P, Guillet-Rosso F, et al. Sperm factors related to failure of human in-vitro fertilization. J Reprod Fertil 1986; 76: 735-44.

16 Jouannet P, Ducot B, Feneux D, Spira A. Male factors and the likelihood of pregnancy in infertile couples. I. Study of sperm characteristics. Int J Androl 1988; 11: 379-94.
17 Menkveld R, Rhemrev JP, Franken DR, Vermeiden JP, Kruger TF. Acrosomal morphology as a novel criterion for male fertility diagnosis: relation with acrosin activity, morphology (strict criteria), and fertilization in vitro. Fertil Steril 1996; 65: 637-44.

18 Slama R, Eustache F, Ducot B, Jensen TK, Jørgensen N, et al. Time to pregnancy and semen parameters: a cross-sectional study among fertile couples from four European cities. Hum Reprod 2002; 17: 503-15.

19 Swan SH, Brazil C, Drobnis EZ, Liu F, Kruse RL, et al. Study For Future Families Research Group. Geographic differences in semen quality of fertile U.S. males. Environ Health Perspect 2003; 111: 414-20.

20 Haugen TB, Egeland T, Magnus O. Semen parameters in Norwegian fertile men. J Androl 2006; 27: 66-71.

21 Paasch U, Salzbrunn A, Glander HJ, Plambeck K, Salzbrunn $\mathrm{H}$, et al. Semen quality in sub-fertile range for a significant proportion of young men from the general German population: a co-ordinated, controlled study of 791 men from Hamburg and Leipzig. Int J Androl 2008; 31: 93-102.

22 Guzick DS, Overstreet JW, Factor-Litvak P, Brazil CK, Nakajima ST, et al. Sperm morphology, motility, and concentration in fertile and infertile men. N Engl J Med 2001; 345: 1388-93.

23 Auger J, Eustache F. Standardisation de la classification morphologique des spermatozoïdes humains selon la méthode de David modifiée. Andrologie 2000; 10: 358-73.

24 Auger J, Eustache F, Andersen AG, Irvine DS, Jørgensen N, et al. Sperm morphological defects related to environment, lifestyle and medical history of 1001 male partners of pregnant women from four European cities. Hum Reprod 2001; 16: 2710-7.

25 Chemes EH, Rawe YV. Sperm pathology: a step beyond descriptive morphology. Origin, characterization and fertility potential of abnormal sperm phenotypes in infertile men. Hum Reprod Update 2003; 9: 405-28.

26 Lähdetie J. Occupation- and exposure-related studies on human sperm. J Occup Environ Med 1995; 37: 922-30.

27 Jensen TK, Bonde JP, Joffe M. The influence of occupational exposure on male reproductive function. Occup Med (Lond) 2006; 56: 544-53.

28 Bigelow PL, Jarrell J, Young MR, Keefe TJ, Love EJ. Association of semen quality and occupational factors: comparison of casecontrol analysis and analysis of continuous variables. Fertil Steril 1998; 69: 11-8.

29 Tielemans E, van Kooij R, te Velde ER, Burdorf A, Heederik D. Pesticide exposure and decreased fertilisation rates in vitro. Lancet 1999; 354: 484-5.

30 Wyrobek AJ. Changes in mammalian sperm morphology after X-ray and chemical exposures. Genetics 1979; 92 (Suppl): s105-19.

31 Giblin PT, Poland ML, Moghissi KS, Ager JW, Olson JM. Effects of stress and characteristic adaptability on semen quality in healthy men. Fertil Steril 1988; 49: 127-32.

32 Mayaux MJ, Schwartz D, Czyglik F, David G. Conception rate according to semen characteristics in a series of 15364 insemination cycles: results of a multivariate analysis. Andrologia 1985; 17: 9-15.

33 Auger J, Mesbah M, Huber C, Dadoune JP. Aniline blue staining as a marker of sperm chromatin defects associated with different semen characteristics discriminates between proven fertile and suspected infertile men. Int J Androl 1990; 13: 452-62. 
34 Menkveld R, Kruger FT. Basic semen analysis. In: Acosta AA, Kruger TF, editors. Human Spermatozoa in Assisted Reproduction. Carnforth: Parthenon Publishing; 1996. p53-71.

35 Menkveld R, Wong WY, Lombard CJ, Wetzels AM, Thomas $\mathrm{CM}$, et al. Semen parameters, including WHO and strict criteria morphology, in a fertile and subfertile population: an effort towards standardization of in-vivo thresholds. Hum Reprod 2001; 16: 1165-71.

36 Aziz N, Buchan I, Taylor C, Kingsland CR, Lewis-Jones I. The sperm deformity index: a reliable predictor of the outcome of oocyte fertilization in vitro. Fertil Steril 1996; 66: 1000-8.

37 Aziz N, Agarwal A, Lewis-Jones I, Sharma RK, Thomas Jr. AJ. Novel associations between specific sperm morphological defects and leukocytospermia. Fertil Steril 2004; 82: 621-7.

38 Aziz N, Said T, Paasch U, Agarwal A. The relationship between human sperm apoptosis, morphology and the sperm deformity index. Hum Reprod 2007; 22: 1413-9.

39 Eustache F, Auger J. Inter-individual variability in the morphological assessment of human sperm: effect of the level of experience and the use of standard methods. Hum Reprod 2003; 18: 1018-22.

40 Cooper TG, Neuwinger J, Bahrs S, Nieschlag E. Internal quality control of semen analysis. Fertil Steril 1992; 58: 172-8.

41 Cooper TG, Atkinson AD, Nieschlag E. Experience with external quality control in spermatology. Hum Reprod 1999; 14: 765-9.

42 Moruzzi JF, Wyrobek AJ, Mayall BH, Gledhill BL. Quantification and classification of human sperm morphology by computer-assisted image analysis. Fertil Steril 1988; 50: 142-52.

43 Davis RO, Bain DE, Siemers RJ, Thal DM, Andrew JB, et al. Accuracy and precision of the CellForm-Human automated sperm morphometry instrument. Fertil Steril 1992; 58: 763-9.

44 Kruger TF, du Toit TC, Franken DR, Menkveld R, Lombard CJ. Sperm morphology: assessing the agreement between the manual method (strict criteria) and the sperm morphology analyzer IVOS. Fertil Steril 1995; 63: 134-41.

45 Coetzee K, de Villiers A, Kruger TF, Lombard CJ. Clinical value of using an automated sperm morphology analyzer (IVOS). Fertil Steril 1999; 71: 222-5.

46 Davis RO, Gravance CG. Standardization of specimen preparation, staining, and sampling methods improves automated sperm-head morphometry analysis. Fertil Steril 1993; 59: 412-7.

47 Gandini L, Lombardo F, Paoli D, Caponecchia L, Familiari $\mathrm{G}$, et al. Study of apoptotic DNA fragmentation in human spermatozoa. Hum Reprod 2000; 15: 830-9.

48 Prisant N, Escalier D, Soufir JC, Morillon M, Schoevaert D, et al. Ultrastructural nuclear defects and increased chromosome aneuploidies in spermatozoa with elongated heads. Hum Reprod 2007; 22: 1052-9.

49 Benzacken B, Gavelle FM, Martin-Pont B, Dupuy O, Lièvre N, et al. Familial sperm polyploidy induced by genetic spermatogenesis failure: case report. Hum Reprod 2001; 16: 2646-51.

50 Courtot AM, Escalier D, Jouannet P, David G. Impaired ability of human spermatozoa to penetrate zona-free hamster oocytes: is a postacrosomal sheath anomaly involved? Gamete Res 1987; 17: $145-56$.

51 Longo FJ, Krohne G, Franke WW. Basic proteins of the perinuclear theca of mammalian spermatozoa and spermatids: a novel class of cytoskeletal elements. J Cell Biol 1987; 105: 1105-20.

52 Escalier D. Failure of differentiation of the nuclear-perinuclear skeletal complex in the round-headed human spermatozoa. Int
J Dev Biol 1990; 34: 287-97.

53 Albert M, Gallo JM, Escalier D, Parseghian N, Jouannet P, et al. Unexplained in-vitro fertilization failure: implication of acrosomes with a small reacting region, as revealed by a monoclonal antibody. Hum Reprod 1992; 7: 1249-56.

54 Holstein AF, Schirren CG, Schirren C, Mauss J. Round headed spermatozoa: a cause of male infertility. Dtsch Med Wochenschr 1973; 98: 61-2.

55 Gomez E, Buckingham DW, Brindle J, Lanzafame F, Irvine DS, et al. Development of an image analysis system to monitor the retention of residual cytoplasm by human spermatozoa: correlation with biochemical markers of the cytoplasmic space, oxidative stress, and sperm function. J Androl 1996; 17: 27687.

56 Zamboni L. Sperm structure and its relevance to infertility. An electron microscopic study. Arch Pathol Lab Med 1992; 116: 325-44.

57 Chemes HE, Puigdomenech ET, Carizza C, Olmedo SB, Zanchetti F, et al. Acephalic spermatozoa and abnormal development of the head-neck attachment: a human syndrome of genetic origin. Hum Reprod 1999; 14: 1811-8.

58 Saïas-Magnan J, Metzler-Guillemain C, Mercier G, CarlesMarcorelles F, Grillo JM, et al. Failure of pregnancy after intracytoplasmic sperm injection with decapitated spermatozoa: case report. Hum Reprod 1999; 14: 1989-92.

59 Chemes HE, Olmedo SB, Carrere C, Oses R, Carizza C, et al. Ultrastructural pathology of the sperm flagellum: association between flagellar pathology and fertility prognosis in severely asthenozoospermic men. Hum Reprod 1998; 13: 2521-6.

60 Feneux D, Serres C, Jouannet P. Sliding spermatozoa: a dyskinesia responsible for human infertility? Fertil Steril 1985; 44: 508-11.

61 Lampiao F, du Plessis SS. Comparing the multi-ZSC onestep standardized swim-up method to the double-wash swimup method with regard to the effects of sperm separation on morphology, head morphometry, and acrosome reaction inducibility. Fertil Steril 2006; 86: 739-41.

62 Ramos L, Hendriks JC, Peelen P, Braat DD, Wetzels AM. Use of computerized karyometric image analysis for evaluation of human spermatozoa. J Androl 2002; 23: 882-8.

63 Spermon JR, Ramos L, Wetzels AM, Sweep CG, Braat DD, et al. Sperm integrity pre- and post-chemotherapy in men with testicular germ cell cancer. Hum Reprod 2006; 21: 1781-6.

64 Zavaczki Z, Celik-Ozenci C, Ovari L, Jakab A, Sati GL, et al. Dimensional assessment of X-bearing and Y-bearing haploid and disomic human sperm with the use of fluorescence in situ hybridization and objective morphometry. Fertil Steril 2006; 85: 121-7.

65 Garrett C, Liu DY, Clarke GN, Rushford DD, Baker HW. Automated semen analysis: 'zona pellucida preferred' sperm morphometry and straight-line velocity are related to pregnancy rate in subfertile couples. Hum Reprod 2003; 18: 1643-9.

66 Gergely A, Kovanci E, Senturk L, Cosmi E, Vigue L, et al. Morphometric assessment of mature and diminished-maturity human spermatozoa: sperm regions that reflect differences in maturity. Hum Reprod 1999; 14: 2007-14.

67 Fenster L, Katz DF, Wyrobek AJ, Pieper C, Rempel DM, et al. Effects of psychological stress on human semen quality. J Androl 1997; 18: 194-202.

68 Schrader SM, Turner TW, Simon SD. Longitudinal study of semen quality of unexposed workers: sperm head morphometry. J Androl 1990; 11: 32-9. 